\title{
Building Humanistic Education and Management Mode Based on Humanistic Education Beliefs
}

\author{
Lili Liu ${ }^{1, a^{*}}$ and Xuehong Chang ${ }^{1, b}$ \\ ${ }^{1}$ Jilin Agricultural University, Changchun, 130118, China \\ a79856004@qq.com, b66414623@qq.com
}

Keywords: Humanistic Education; Humanism; Education; Management; Mode

\begin{abstract}
The most fundamental nature of humanistic education is to take people as the focus. Under the circumstance that quality education reform and higher education becomes more massorientated, only by taking people as the focus, fully developing the potential of people, can we cultivate real talents. Humanistic education beliefs are modern education management concepts conforming to the era, and can be deemed as new positioning of value. In colleges, humanistic education takes students as the focus and colleges build humanistic education as well as management mode based on it.
\end{abstract}

\section{Introduction}

The concept of humanistic education conforms to the quality education reform trend, which also becomes the core of education development. In addition, education philosophy is experiencing challenges in this knowledge-based economy era. What's more, colleges as the bases to output professional talents, should pay attention to dig into the potential of students and improve their allround quality, in another world, take people-orientation as the fundamental.

\section{Overview of Humanistic Education Beliefs}

Concerning the sustainable education philosophy, the core of people development should put education in the primary place. What's more, the teaching activity implementation should also take students as the core, when students are exposed to education, they should set the idea that they will study for their entire life because people are the main bodies of education and are the goal. Humanistic education beliefs emphasize that in the process of education management, we will take people as the core and education management in colleges should take students as main bodies, which can be deemed as the demonstration of humanistic education. Based on this, we can implement comprehensive, multi-perspectives and all-round education to help students realize their individual and social values. To take students as the core is to respect their different characteristics, deeply dig into their potential and carry out humanistic education as well as management rather than managing them based on rigid discipline. It is not about collecting them into a united development mode but developing their mind and potential, adopting different education means based on their different characteristics so as to let them be exposed to proper education and let them become successful in their profession to realize individual value and let teaching benefits both students and teachers.

\section{Importance for Colleges to Adhere to the Humanistic Education and Management Beliefs}

Satisfy the Requirement of Development in New Trend. The education management in colleges is a complicated and long-term course which needs proper education methods to help teaching activities achieve certain goals of cultivating talents, and it is also the guarantee to keep the normal operation of school. Education management should guarantee the smooth cooperation of various sectors pf education, including talents cultivation modes, subject construction, teaching activities operation, course setting, college regulations etc. All sectors of education and both internal as well 
as external factors are interrelated. No matter which factor changes, it will affect the ultimate goal of education. The main subjects and objects of education are students, therefore, college management departments have to well manage it.

Satisfy the Requirement of Development in New Trend. Along with the establishment of market economy system, the approaching of free economic times, the mass-orientation of higher education, the main task of colleges is to cultivate talents who can serve the society. Concerning the education in colleges, students, as the main bodies, they are granted the right to choose the type of education. Especially in the knowledge-based economic era, the education in colleges is of pivotal importance and how to output innovative talents should be the question that college education has to figure out in the new era. The knowledge-based economic era highlights the importance of human resources and technological innovation, while people are the carriers of knowledge, so colleges should take humanistic education beliefs as the core. In addition, with the population of college education and the expansion of college enrollment, the college education is no longer only for elites but becomes mass-oriented. Therefore, colleges should adhere to human orientation and establish an open education management mode.

Change the Traditional Education Management Mode. Traditional education philosophy manages students and aims to maintain the order of education by establishing a series of regulations. In terms of education, colleges kill the personality of students; in terms of professional cultivation, they ignore the practical training and requirement of employment as well as the improvement of their abilities. What's more, traditional courses arrangement cannot suit the massorientated education mode because the personality of students is killed and the knowledge structure is single; in terms of assessment means, single exam results cannot reflect the real ability of students. Traditional education has weak service consciousness, which ignores the real needs of teachers and students. It aims to improve the administration ability and limits the development of both teachers and students. In addition, people who are engaged in education management are not professional and they have never been exposed to management education. They carry out management based on experience and do not have ability to study on management, let alone creative management methods.

\section{Construct Humanistic Education and Management Mode}

Build People-Oriented Education and Management Beliefs. To stick to people orientation is to satisfy the education management needs of both teachers and students and start from their benefits. What's more, we have to respect and understand students. In terms of management mode, we have to change the pressing management mode into a mode that students can directly participate in and they play the leading role. In terms of professional education, we have to respect their willing and provide excellent service for them. To respect teachers is to respect the achievement of them, initiate their passion and encourage them to participate in education management. In daily activities, teachers directly connect with students and they are familiar with them. Therefore, they have the right to talk about students. In a free environment, the education quality will be related to the overall condition of schools. What's more, in terms of education management, colleges should encourage soft management and invest more time and passion so as to ignite the passion of both students and teachers because soft management can be easily accepted by the management subjects. Based on this, both students and teachers will contribute to the education management and relative personnel have to well understand the ideas of students and establish authority among teachers and students with charm by considering from the perspective of teachers and students.

Perfect People-Oriented Education and Management System. First, Humanistic ideas are infiltrated in education and management system, every sector of college education management cannot be separated and they are closely tied together. Teaching plans, as the initial step of education management is to study on how to cultivate talents, aiming to coordinate the contents, quality, Schedule of education management. All management work should take teaching plans as the base and try to cultivate talents, improve the all-round ability of students, and help students establish good morality, broaden their horizon and improve abilities. Secondly, in daily teaching 
activities, the core content is education and we have to properly adjust teaching activities to maintain the normal operation. Therefore, in class teaching, we have to fully play the subject role of teachers and students, develop the college entrance exam and try to cancel the means to determine the final result based on the terminal examination and focus on their comprehensive abilities. Thirdly, in terms of monitoring teaching quality and evaluation system, we have to focus on teachers and they are not the subjects being monitored and can play a role in serving and guiding. Furthermore, we can evaluate students based on development assessment and take into consideration their individual development and benefits so as to encourage them.

Perfect the Humanistic Education Management System. The education management system is the one to coordinate and organize teaching activities in the premise of developing talents, which can effectively regulate teaching activities and maintain the teaching order as well as guarantee the education quality. While formulating and modifying the education management system, we have to let teachers and students positively participate and ignite their enthusiasm, listen to their suggestions. Colleges should also adopt various means to guarantee the right of participation, to know and suggest. In terms of academic records, we have to change the four-year system and let students flexibly select courses and teachers based on their interest. In addition, colleges should pay more attention to the appealing of teachers, change traditional structure management mode, take teachers' benefits into consideration and provide a broad platform for teachers and avoid a compulsory management mode. While implementing, we should take into consideration of the management identity of teachers, trust them and respect them rather than single blaming. For those students with less experience, we should leave space for their career development. In addition, students should not blame them but allow some mistakes and give them more opportunities. All in all, while formulating and implementing education management system, we should focus on their opinions and improve the elasticity of regulations to give teachers and students more space.

Construct Education Management System Based on Humanistic Philosophy. Firstly, adopt emotional encouragement to care about the education management. Emotion can be deemed as the incentive system while doing everything. College leaders should start from the perspective of education and management personnel, understand their work nature, respect their work position so as to encourage their passion and trigger the internal incentive. In addition, colleges can regularly hold meetings about education and management, listen to the suggestions of front-line workers. Secondly, adopt goal inspiration to ignite the passion of relative personnel. Colleges can set goals to combine the needs of education personnel and targets of schools to bring their enthusiasm into play. However, the goal setting should be realistic so as to let them feel the possibility. Thirdly, improve the management quality and ability of management personnel by training. Colleges should encourage relative management personnel to do reeducation so as to develop their professional management quality and carry out regular training to improve their abilities in terms of solving problem. By the way, the lectures can also enable relevant personnel to communicate and exchange views. Fourthly, perfect the award and punishment system, improve the attraction of positions. Colleges should perfect the evaluation system to comprehensively assess management personnel and give obvious award and punishment. For those who always shine out, colleges should timely give awards and recognize them in commendation meeting with both spiritual and material awards. And in terms of promotion, colleges can relax the restrictions to trigger their management passion.

\section{Conclusion}

We should construct the humanistic education management mode based on the humanistic education philosophy and adhere to the humanistic education philosophy, perfect it's system, take the benefits of teachers and students as primary contents to let them participate in the regulations formulating procedure. In addition, we should also listen to the appealing of both teachers and students and carry out flexible management mode, and change the compulsory mode. The author depicts the importance of humanistic ideas and come up with an innovative and humanistic college education management mode, hoping that it will be beneficial to college education management. 


\section{References}

[1] L.Y. Xu, Reflection on People-oriented College Education and Management System [J]. Journal of Fujian Agriculture and Forestry University (Philosophy and Science) (2004) No.7, p.53-56

[2] X.N. Zhu, People-oriented Teacher Management Mechanism and Motivational Strategy [J].Maritime Education Research, (2006 )No.2,p.79 - 81

[3] S.A. Zhao, School Management-People-orientation-Application of Soft Management in School Management [J]. Jiangxi Education Research (2001) No.12, p.39-40

[4] Y. Song Discuss on the application of People-oriented Management Ideas in School Development [J]. Journal of Wuhan Education Institute, (2001) No.4 ,p.86 - 89

[5] T.X. Xu, Higher Education. Guilin: Guangxi Normal University Press, 2001

[6] Y.Q. Zhang, Reflection and Construction of Modern Higher Education. Harbin, Heilongjiang Education Press, 2000

[7] C. Xiao, The ideas and Philosophy of Education. Changsha: Yuelu Book Society, 2002:56

[8] N.L. Chen, Overview of Humanistic Education Philosophy [J] Jiangsu Higher Education, (2005) No.1

[9] Y.L. Li, Theory and Practice of Hang-in-Hand Education [J] Journal of Liaoning Teachers College (Social Science Edition), (2013) No.6

[10]L.J. Luo, Humanistic Education [M] Beijing: Chinese Economy Press, (2004) No .5

[11]X.L. Wu Xiaoliang. Study on the Operation Mode of Hand-in-Hand Education from the Perspective of College Ideological and Political Theory [J]. Journal of Jiangsu Education Institute

[12]W. Zhu, Establish People-Oriented Math Education, Focus on Cultivating Students' Math Interest[J].Journal of Higher Education, (2005) No.3,23-4 